\begin{tabular}{c} 
Volume and Issues Obtainable at Center for Sustainability Research and Consultancy \\
Journal of Business and Social Review in Emerging Economies \\
ISSN: 2519-089X (E): 2519-0326 \\
Volume 7: Issue 3September 2021 \\
¿SRᄃ \\
Journal homepage: www.publishing.globalcsrc.org/jbsee \\
\hline
\end{tabular}

\title{
Assessing Institutional Preparedness of Pakistani Medical Schools towards Curriculum Change Using MORC
}

*Ayesha Sadiq, MHPE Scholar, the University of Lahore, Pakistan

Rehan Ahmad Khan, Assistant Dean Medical Education and Professor of Surgery, Islamic International Medical College, Riphah International University, Pakistan

Babak Mahmood, Associate Professor, Department of Sociology, Government College University, Faisalabad, Pakistan

Muhammad Furqan Ashraf, Visiting Faculty, Department of Sociology, Government College

University, Faisalabad, Pakistan

*Corresponding author's email address: dr.ayesha.sadiq@gmail.com

\begin{tabular}{l}
\hline ARTICLEDETAILS \\
\hline History \\
Revised format: Aug2021 \\
Available Online: Sep2021 \\
\hline Key words \\
Curriculum Change, \\
Organizational Readiness \\
and Institutional \\
Preparedness, MORC, \\
Medical Schools \\
\hline
\end{tabular}

JEL Classification

A20, A29 \begin{abstract}
Purpose: Changing community needs and disease patterns are the major stimulator for change in medical curriculum throughout the world. The process of change depends on many factors that come under the umbrella of organizational readiness for its successful implementation. Inappropriate planning and low levels of organizational readiness for change will result in failure of change process.

Methodology: A quantitative study design was chosen for this study. Medical school's organizational readiness questionnaire (MORC) was used to collect data. The questionnaire consists of 53 items further categorized into three scales and twelve subscales. The questionnaire was distributed among faculty members of four medical colleges of Punjab, collected data was coded and descriptive and inferential statistics were applied for analysis using SPSS. Analysis revealed that all four medical colleges were having good organizational readiness to adopt change.

Findings: The results of descriptive analysis showed, that majority of the respondents $(47 \%)$ were agreed that their medical school, is in preparatory phase, 29\% respondents showed that their institute is in more than two years of implementation phase of curriculum change, $23.8 \%$ agreed that in their medical school is in first two years of implementation phase.
\end{abstract}

Implication: MORC is a reliable instrument for assessing institutional preparedness for curriculum change.

(C) 2021 The authors, under a Creative Commons AttributionNonCommercial 4.0

Recommended citation: Sadiq, A., Khan, R. A., Mahmood, B. And Ashraf, M. F. (2021). Assessing Institutional Preparedness of Pakistani Medical Schools towards Curriculum Change Using MORC. Journal of Business and Social Review in Emerging Economies, 7 (3), 687-698. 


\section{Introduction \\ Curriculum Change}

In medical education, curriculum not only deals with learners, but it also addresses to the current issues and problems that affects the community. Therefore, Changes in medical school's curriculum in response to changing disease patterns, community healthcare needs, medical student's needs, advancing teaching and learning strategies, is in-vogue worldwide(Garrison \& Vaughan, 2013).

The need for reforms/changes in medical education initiated with Flexner Report in 1910. The report emphasized to integrate modern sciences in medical school's curriculum, in order to equip healthcare professional with knowledge that will help them to improve quality of life, better control of diseases and overall improvement of healthcare system. But the gaps and differences in community needs and healthcare provision persists still in $21^{\text {st }}$ century, therefore providing a source of stimulation for medical schools to change their curricula continuously and produce competent healthcare professionals(Bland, Starnaman, Wersal, Moorhead-Rosenberg, et al., 2000).

The term 'curriculum change' refers to any "innovation that leads to improvement of currently existing curriculum"(Arvandi, Emami, Zarghi, \& Education, 2015). Curriculum change ranges from implementation of a single innovation tochange of entire educational system(Fullan Dingle Associates, Inc., Washington \& Michael Dingle Associates, Inc., Washington, 1983).

The process of change has got 4 different stages; planning, development, implementation, and institutionalization(Bland, Starnaman, Wersal, Moorhead-Rosenberg, et al., 2000). A lot of time, energy and resources are needed to successfully implement the change process. For a successful change all the stakeholders i.e. institutional leadership, faculty and students, must be on the same page and should feel the ownership of their responsibilities right from the beginning that is planning phase, till the complete implementation that is institutionalization phase of the change process(Bland, Starnaman, Wersal, Moorhead-rosenberg, et al., 2000).Imposed changes without proper need identification, ineffective leadership, Faculty resistance, institutional politics and unavailability of resources are the major issues that can often lead to failure of the change process(Frenkel et al., 2007).

\section{Organizational Readiness}

Despite hard work and proper resource allocation, successful implementation of change is difficult to achieve. No data is available that document the failure rate of change in medical schools, on the basis of literature review, many factors are identified that can either facilitate or impede the process of change. These factors include: leadership, time, financial resources, ownership, collaboration among departments, and communication(Hubball\& Burt, 2004)(Bland, Starnaman, Wersal, Moorhead-rosenberg, et al., 2000). These factors determine the organizational readiness for curriculum change.The higher levels of organizational readiness ensure successful implementation of change in healthcare organizations as well as business organizations(Weiner, Amick, \& Lee, 2008).

The beliefs and attitude of organizational members regarding need to change and capability of organization to successfully implement the change reflects the organizational readiness of an institute(Alharbi, n.d.). Organizations in which level of readiness is high, the employees are committed to invest in the change process, and are ready to face obstacles openheartedly. They make efforts to improve the system in order to resolve the issues, thereby ensuring successful implementation of change. In organizations with low levels of readiness, the change process may culminate in failure due to strong faculty resistance, being the major cause(Weiner et al., 2008).

\section{Curriculum Changes in Pakistan}

The curriculum provided by PM\&DC in 2011 demands a seven-star doctor having following 
competencies: skillful, knowledgeable, community health promoter, problem solver, professionalism, researcher and role model. Unfortunately, the doctors produced by our system lacking many of the competencies listed by PM\&DC. Most of the institutes are still following the discipline-based curriculum in Pakistan. The major pitfall of this curriculum is, that it imparts unnecessary information and results in student's stress and burnout(Salam, Yousuf, Muhammad, Bakar, \& Haque, 2013). They are reluctant to adopt changes because of unavailability of resources and mainly the resistance from faculty because of increase in workload resulting from change(Arvandi et al., 2015).

The wave of change also involved some of the Pakistani medical schools. These institutes took initiative and adopted curricular changes in order to, overcome the issue of inequality between community needs and provision of healthcare facilities.

\section{Purpose of the Study}

The purpose of the study is to establish reliability of "Medical School's Organizational readiness for curriculum change (MORC)" questionnaire in Pakistani setup. MORC is a valid and reliable instrument for measuring organizational readiness for curriculum change in medical schools worldwide. This instrument will help the institutes to identify those elements, which requires special attention to ensure successful implementation of change. MORC is a 53-item scale; these items are arranged within 12 subscales and 3 major scales respectively.

\section{Rationale/Justification}

Planning and adopting curricular changes without appropriate preparations can affect the efficacy of the newly adopted curriculum. Each stage of curriculum change requires proper planning, allocation of resources and trained faculty for successful implementation of curriculum. Therefore, any institution going to adopt change must ensure the availability of resources; prepare the faculty for change accordingly(Bland, Starnaman, Wersal, Moorhead-Rosenberg, et al., 2000).

PM\&DC (the accreditation body for medical schools in Pakistan), has enlisted the resources required for both, discipline based and integrated curriculum, in 2011 curriculum guidelines. But it does not provide any information, for how to deal with the behavioral and psychological issues related to faculty burnout associated with change process. Also, there are no guidelines regarding faculty resistance, leadership, teamwork and management of change process. These are the issues to be considered before going under the process of curriculum change, to determine the level of preparedness for change; otherwise the failure will be the outcome of the change process. This instrument was created to measure the level of institutional preparedness beforehand. In this study this instrument will be checked for its reliability, and the level of preparedness of institutes will also be assessed.

\section{Operational and Constitutive Definitions of Key terms}

\section{Change}

1. An event that occurs when something passes from one state or phase to another phase.2. Change is a process in which there are number of stages and steps that are to be considered moving from one phase to another(Gene \& Shirley, 2012).

\section{Curriculum}

1. An integrated course of academic studies.

2. Curriculum is a 'planned educational experience that encompasses behavioral goals, instructional methods and actual experiences of the learner'(Mcleod \& Steinert, 2014).

\section{Preparedness}

1. The state of having been made ready or prepared for use or action.

2. Prevailing beliefs and attitudes among members of an organization regarding the necessity and urgency of change and in the capacity of the organization to successfully implement change(Jippes 
et al., 2013)

\section{Research Questions}

1. Is MORC is a reliable tool to measure institutional preparedness of medical schools of Pakistan for curriculum change?

2. What is the level of preparedness of Pakistani medical schools to adopt curriculum changes?

\section{Research Objectives}

The objectives of this study are;

1. To establish reliability of MORC in Pakistani Medical schools.

2. To measure the level of institutional preparedness for curriculum change

\section{Literature Reviewed}

Changing societal needs and disease patterns day-to-day, serves as a powerful precursor of curriculum change throughout the world. Renewal of already existing curriculum or complete change of curriculum, both are challenging. It requires a lot of energy and resources for the change process to be successful.

\section{Curriculum Change}

The term 'curriculum change' refers to "any innovation that leads to improvement of currently existing curriculum"(Arvandi et al., 2015). The process of change ranges from an introduction of a singleinnovation to complete change of system(Fullan Dingle Associates, Inc., Washington \& Michael Dingle Associates, Inc., Washington, 1983). In medical education, curriculum not only deals with learners but it also addresses to the current issues and problems that affects the community(Garrison \& Vaughan, 2013). Since 1910, after Flexner's report, the medical education is continuously subjected to change(Bland, Starnaman, Wersal, Moorhead-Rosenberg, et al., 2000). Changing disease patterns, community needs, student needs, and advancements in teaching and learning strategies remained the basic stimulators behind curriculum change worldwide(Frenkel et al., 2007). The curriculum change process has got 4 different stages; planning, development, implementation, and institutionalization. Each stage requires a large number of resources and devoted faculty to make the change successful. For a successful change all the stakeholders must be on the same page and should feel the ownership of their responsibilities right from the time of planning till the institutionalization of the change(Bland, Starnaman, Wersal, Moorhead-Rosenberg, et al., 2000). Changes that are imposed without proper need identification, ineffective leadership, Faculty resistance, institutional politics and unavailability of resources are the major issues that can lead to failureof the change process(Frenkel et al., 2007).

\section{Organizational Readiness for Change}

Planning and adopting curricular changes without appropriate preparations can affect the efficacy of the newly adopted curriculum. Each stage of curriculum change requires proper planning, adequate availability and allocation of resources, appropriate institutional environment and trained faculty to run the implemented system successfully. Therefore, the issues to be dealt on priority basis by any institution going to adopt curriculum change are; availability of resources and preparation of the faculty for change(Frenkel et al., 2007).

The major problems faced by the organizations during change process are:

1. Employee resistance

2. Inadequate resources

3. High expectations from the change process

4. No proper plans to implement change

The most acceptable model for curriculum change was proposed by Kurt Lewin. This three-step model suggested that a planned change process can help the organization to overcome the issues related to 
change process. The three steps are; unfreezing, change and refreezing. The first step that is 'unfreezing' corresponds to the organizational readiness for change process. The key concept of this step is to help organizational members to unlearn old ways and develop openness for the adaptation of change process. The role of an authentic and influential leadership cannot be denied in change process(Bakari, Hunjra, \& Niazi, 2017).

The theory of organizational readiness for change stated that, "it is a shared psychological state in which the organizational members feel committed in implementing change and confident in their collective ability to do so'. According to this theory the change process consists of two elements; change commitment and change efficacy. For change commitment change valence is necessary i.e. whether the members value the process of change or not?(Weiner et al., 2008). Change valence is based on motivational theory(Meyer \& Herscovitch, 2001), whereas change efficacy is on based implementation theory(Klein \& Knight, 2005). It deals with the issues of implementation of change in an organization and it's ability to overcome these issues.

\section{Factors Influencing Curriculum Change}

Curriculum change is a complex, and multifaceted process(Hubball\& Burt, 2004). The process of change is affected by many factors including; social, political, economic, organizational, cultural and individual. It involves people at various levels including, administrators, curriculum development committee personnel, instructors and learners and their openness to adopt the change(Wanberg\& Banas, 2000). The factors can be classified as(Bland, Starnaman, Wersal, Moorhead-Rosenberg, et al., 2000);

1. Institutional infrastructure and environment related factors, including Mission and goal, History of change, Politics (internal and external), proper resource allocation, Collaboration among departments and individual faculty members.

2. Factors related to curriculum includes, proper need identification, scope of change and complexity of change.

3. Factors related to implementation involves; Co-operative environment, Active participation by members of team, Proper communication about curriculum, faculty training, support and reward system for employees(Frenkel et al., 2007)(Garrison \& Vaughan, 2013).

4. Other factors include authentic leadership to keep the leader employee relationship dynamic. Top down pressure for change is also act as a useful precursor for change(Bakari et al., 2017).

Quantitative descriptive cross-sectional study design was used. Descriptive research is an appropriate choice when the research aim is to identify characteristics, frequencies, trends, correlations, and categories(Yilmaz, 2013).The reason for choosing this study design lies in the fact that, curriculum change is a complex process and many factors can affect its implementation, by using this study design the researcher can cover almost all aspects of institutional readiness for successful implementation of curriculum change. Population of current research was consisted of student of four medical colleges of Pakistan. Purposive sampling technique was used to select sample. 160 faculty members from four medical colleges were selected (University college of Medicine and Dentistry, University of Lahore, Aziz Fatima medical college Faisalabad, Punjab medical college, Faisalabad medical university, University medical and dental college, Faisalabad). This sampling strategy is employed when there is a very large pool of potentially information-rich cases and no obvious reason to choose one case over another(Sandelowski, 2000). The study was started after taking approval from "Advanced Studies \& Research Board" of the University of Lahore and Institutional review board approval from Punjab medical college, Faisalabad, Aziz Fatimah medical college, Faisalabad, and university medical and dental college, Faisalabad. Study was conductedfromNovember 2016 to May 2017. Data was collected by using MORC (medical schools' organizational readiness for change) questionnaire. This instrument was used after taking permission from its authorMerrielJippes. For the purpose of data collection, researcher used questionnaire and distributed among faculty members, after collecting back filled questionnaires, these questionnaires were processed $\mathrm{f}$ for analysis. For analysis data obtained from the questionnaire was entered in the SPSS software manually by the researcher. Descriptive statistics were applied for 
analysis. The descriptive analysis deals with frequency analysis, mean and standard deviation of all indicators.

\section{Instrument}

This instrument is already tested for its validity and reliability internationally. The scale consists of 53 items, categorized in 3 main scales and 12 subscales(Jippes et al., 2013). The questionnaire was developed in 2012, the face validity of the questionnaire was established using modified Delphi technique. Multiple rounds were conducted with experts to examine the applicability of the questionnaire. After that the questionnaire was administered to the faculty members of medical schools of different countries. Initially the questionnaire consisted of 65 items. After data collection, it was analyzed using structural equation modeling software Mplus (version 5.21, Los Angeles, California) for EFA and CFA, urGENOVA software (version 2.1, Iowa City, Iowa) to analyze generalizability, and SPSS (version 19, Armonk, New York) for all the other analyses.

\section{Overall Reliability of Instrument}

Cronbach's Alpha test was applied to determine the internal reliability of the questionnaire, the alpha value as under.

\begin{tabular}{cc}
\hline \multicolumn{2}{c}{ Reliability Statistics } \\
\hline Cronbach's Alpha & No of Items \\
0.891 & 53 \\
\hline
\end{tabular}

The reliability of the instrument was computed as .891 that was excellent for research work.Cronbach's alpha reliability coefficient normally ranges between 0 and 1 . However, there is actually no lower limit to the coefficient. The closer Cronbach's alpha coefficient is to 1.0 the greater the internal consistency of the items in the scale. Based upon the formula ${ }_{-}=\mathrm{rk} /[1+(\mathrm{k}-1) \mathrm{r}]$ where $\mathrm{k}$ is the number of items considered and $\mathrm{r}$ is the mean of the inter-item correlations the size of alpha is determined by both the number of items in the scale and the mean inter-item correlations(Woollins, 1992).

\section{Results and Discussions \\ Descriptive Analysis \\ Level of Curriculum Change of Institutions}

\begin{tabular}{|l|c|c|}
\hline Our medical school is currently in the: & Frequency & Percentage \\
\hline Change is planned but not started yet & 75 & 46.9 \\
\hline $\begin{array}{l}\text { Implementation phase of curriculum change in } \\
\text { first 2 years }\end{array}$ & 47 & 29.4 \\
\hline $\begin{array}{l}\text { Implementation phase of curriculum change } \\
\text { for more than 2 years }\end{array}$ & 38 & 23.8 \\
\hline Total & 160 & 100.0 \\
\hline
\end{tabular}

Table shows the current situation of medical school as predicted by the respondents. The 23.8 respondents told that their medical school is in the implementation phase of curriculum change for more than 2 years. 29 percent respondents showed that their medical school is in first 2 years of implementation phase, while 47 percent respondent showed that in their medical school change is planned but not yet started, which is they are in preparatory phase of curriculum change. 
As mentioned above the MORC questionnaire consist of three main scales; Motivation, Capability and extrinsic pressure. These scales are further categorized into twelve subscales including; pressure for change, need for change, appropriateness (Motivation), efficacy, the leaders of the change project, the implementation team members, staff innovativeness, communication, project resources, and the implementation plan for this change project (capability), external innovativeness inhibition and extrinsic motivation to change(Extrinsic pressure). These subscales consist of 53 indicators.

The indicator wise descriptive analysis of each subscale is given below showing mean, and standard deviation. The indicators within the subscale are ranked on the basis of Mean, the indicator with high Mean value given the rank of 1 .

\section{ANOVA Statistics}

ANOVA is a collection of statistical models and their associated estimation of procedures (such as the variation between and within the groups), used to analyse the differences among group 'Means' in a sample. ANOVA describes change in dependent variable based on the law of total variance, where the observed variance in a particular variable is broken down into components attributed to different sources of variation. Similarly it helps in determining whether they are statistically significant differences between the Means of independent variables.

\section{Comparison of Readiness for Curriculum Change (MORC) among Institutions through ANOVA- Statistics}

\begin{tabular}{|c|c|c|c|c|c|c|}
\hline \multicolumn{7}{|c|}{ ANOVA } \\
\hline & & S.S. & Df & $\begin{array}{l}\text { Mean } \\
\text { Square }\end{array}$ & $\mathrm{F}$ & Sig. \\
\hline \multirow[t]{3}{*}{ Pressure for change } & $\begin{array}{l}\text { Between } \\
\text { Groups }\end{array}$ & .169 & 1 & .169 & .004 & \\
\hline & $\begin{array}{l}\text { Within } \\
\text { Groups }\end{array}$ & 6191.775 & 158 & 39.188 & & $.948^{\mathrm{NS}}$ \\
\hline & Total & 6191.944 & 159 & & & \\
\hline \multirow[t]{3}{*}{ Need for change } & $\begin{array}{l}\text { Between } \\
\text { Groups }\end{array}$ & 8.802 & 1 & 8.802 & 1.896 & \\
\hline & $\begin{array}{l}\text { Within } \\
\text { Groups }\end{array}$ & 733.692 & 158 & 4.644 & & $.171^{\mathrm{NS}}$ \\
\hline & Total & 742.494 & 159 & & & \\
\hline \multirow[t]{3}{*}{ Appropriateness } & $\begin{array}{l}\text { Between } \\
\text { Groups }\end{array}$ & 31.519 & 1 & 31.519 & .831 & \\
\hline & $\begin{array}{l}\text { Within } \\
\text { Groups }\end{array}$ & 5990.725 & 158 & 37.916 & & $.363^{\mathrm{NS}}$ \\
\hline & Total & 6022.244 & 159 & & & \\
\hline \multirow[t]{3}{*}{ Efficacy } & $\begin{array}{l}\text { Between } \\
\text { Groups }\end{array}$ & 50.700 & 1 & 50.700 & 31.328 & \\
\hline & $\begin{array}{l}\text { Within } \\
\text { Groups }\end{array}$ & 255.700 & 158 & 1.618 & & $.000 * *$ \\
\hline & Total & 306.400 & 159 & & & \\
\hline \multirow[t]{3}{*}{$\begin{array}{l}\text { The leaders of this change } \\
\text { project }\end{array}$} & $\begin{array}{l}\text { Between } \\
\text { Groups }\end{array}$ & 1466.502 & 1 & 1466.502 & 173.454 & \\
\hline & $\begin{array}{l}\text { Within } \\
\text { Groups }\end{array}$ & 1335.842 & 158 & 8.455 & & $.000 * *$ \\
\hline & Total & 2802.344 & 159 & & & \\
\hline
\end{tabular}




\begin{tabular}{|c|c|c|c|c|c|c|}
\hline $\begin{array}{l}\text { The implementation team } \\
\text { members }\end{array}$ & $\begin{array}{l}\text { Between } \\
\text { Groups } \\
\text { Within } \\
\text { Groups } \\
\text { Total }\end{array}$ & $\begin{array}{l}226.875 \\
425.500 \\
652.375\end{array}$ & $\begin{array}{c}1 \\
158 \\
159\end{array}$ & $\begin{array}{c}226.875 \\
2.693\end{array}$ & 84.245 & $.000 * *$ \\
\hline Staff innovativeness & $\begin{array}{l}\text { Between } \\
\text { Groups } \\
\text { Within } \\
\text { Groups } \\
\text { Total }\end{array}$ & $\begin{array}{l}110595.408 \\
174442.367 \\
285037.775\end{array}$ & $\begin{array}{c}1 \\
158 \\
159\end{array}$ & $\begin{array}{c}110595.408 \\
1104.066\end{array}$ & 100.171 & $.000 * *$ \\
\hline Communication & $\begin{array}{l}\text { Between } \\
\text { Groups } \\
\text { Within } \\
\text { Groups } \\
\text { Total }\end{array}$ & $\begin{array}{l}1491.075 \\
1373.700 \\
2864.775\end{array}$ & $\begin{array}{c}1 \\
158 \\
159\end{array}$ & $\begin{array}{c}1491.075 \\
8.694\end{array}$ & 171.500 & $.000 * *$ \\
\hline Project resources & $\begin{array}{l}\text { Between } \\
\text { Groups } \\
\text { Within } \\
\text { Groups } \\
\text { Total }\end{array}$ & $\begin{array}{l}151.875 \\
666.100 \\
817.975\end{array}$ & $\begin{array}{c}1 \\
158 \\
159\end{array}$ & $\begin{array}{r}151.875 \\
4.216\end{array}$ & 36.025 & $.000 * *$ \\
\hline $\begin{array}{l}\text { The implementation plan } \\
\text { for this change project }\end{array}$ & $\begin{array}{l}\text { Between } \\
\text { Groups } \\
\text { Within } \\
\text { Groups } \\
\text { Total }\end{array}$ & $\begin{array}{l}285.208 \\
466.767 \\
751.975\end{array}$ & $\begin{array}{c}1 \\
158 \\
159 \\
\end{array}$ & $\begin{array}{c}285.208 \\
2.954\end{array}$ & 96.543 & $.000 * *$ \\
\hline $\begin{array}{l}\text { External innovativeness } \\
\text { inhibition }\end{array}$ & $\begin{array}{l}\text { Between } \\
\text { Groups } \\
\text { Within } \\
\text { Groups } \\
\text { Total }\end{array}$ & $\begin{array}{c}607.500 \\
1190.400 \\
1797.900\end{array}$ & $\begin{array}{c}1 \\
158 \\
159\end{array}$ & $\begin{array}{c}607.500 \\
7.534\end{array}$ & 80.633 & $.000 * *$ \\
\hline $\begin{array}{l}\text { Extrinsic motivation to } \\
\text { change }\end{array}$ & $\begin{array}{l}\text { Between } \\
\text { Groups } \\
\text { Within } \\
\text { Groups } \\
\text { Total }\end{array}$ & $\begin{array}{c}41.419 \\
353.275 \\
394.694\end{array}$ & $\begin{array}{c}1 \\
158 \\
159\end{array}$ & $\begin{array}{l}41.419 \\
2.236\end{array}$ & 18.524 & $.000 * *$ \\
\hline
\end{tabular}

Above table shows comparison of MORC among institutions by using ANOVA statistics. All independent variables were studied; the results revealed that nine out of twelve variables are found significant in causing effect or variation on the dependent variable (organizational readiness for change). Only three variables are found non-significant that are pressure for change, need for change and appropriateness. The results make sense that the respondents have acknowledged that the organizational readiness for change, more out of efficacy than motivation.

\section{Discussions}

Curriculum change is an ongoing process and requires a lot of energy and resources to be successfully implemented. Changes without proper planning and preparation may lead to partial or complete failure of implementation. In Pakistan some medical schools took initiative of curriculum change from discipline based to integrated curriculum. Some of them moved to complete integration of curriculum, whereas some have done only partial integration of curriculum. As the process of curriculum change requires a lot of energy and resources, therefore it is not possible for every institute to go for curriculum change. 
Studiesalso revealed that lack of resources and improper planning can lead to failure of change process. After data collection and arrangement, descriptive statistics were applied for data analysis. Results regarding the level of curriculum change revealed that majority of the respondents (47\%) were agreed and strongly agreed that their medical school is in preparatory phase of curriculum change, that is, change is planned but not yet started. $23.8 \%$ respondents showed that their institute is in implementation phase of curriculum change for more than two years, and $29 \%$ agreed that their medical school is in implementation phase of a curriculum change of first two years.

The first scale of the questionnaire "Motivation" includes three subscales; Pressure for change, Need for change and Appropriateness, which are discussed as follows; There are three pressure groups for curriculum change, bottom up, top down and external pressures. According to the data collected from the respondents, the significant pressure group was 'top-down' including educational committee, deans and rectors of the institutes with a mean of 3.50, 3.40 and standard deviation of 1.405 and 1.278 respectively. The second highest pressure group for curriculum change was accreditation authorities and ministry of health education. The last enticing force for curriculum change was teaching staff, hospital staff and students enrolled in the medical school with the mean of 2.41 and standard deviation of 0.819 . Studies suggest that top down pressures results in more effective changes(Bank et al., 2017).

Need identification is by far the most important step in curriculum change process. The need for curriculum change can be identified by critically reviewing the current and ideal curriculum approaches, to meet the desired outcomes and societal needs(Al-Gindan, Al-Sulaiman, \& Al-Faraidy, 2000)(Tavakol, Murphy, \& Torabi, 2006). In this study most of the respondents agreed that there is a significant difference between current and desired state of curriculum with mean score of 3.58. Theresult indicated that the respondents need a major change in curriculum.(Mcleod\& Steinert, 2014) suggested that proper need identification is a precursor of successful implementation of change. (Bank et al., 2017) posited that appropriateness reflects the belief that specific changes are correct for the situation being addressed. This would help the changes to be successfully implemented and accepted by the stakeholders. The subscale of appropriateness consists of six indicators. The large number of participants of this study suggested that the curriculum change will improve the knowledge and skills of our graduates with mean score of 3.41 and 1.134 standard deviation. Whereas the indicator with lowest $\mathrm{M}=3.02$ and $\mathrm{SD}=1.146$ believe that the change process is tailored to the needs for change in our school.

The theory of organizational readiness defined organizational readiness as, "it is the shared psychological state in which, the members of an organization feel committed to the change process and are confident in their conjoint abilities for successful implementation of change". Task related needs, availability of resources, and situational factors are three possible determinants of the implementation capability. Successful implementation depends on how the organizational members perceive the change, and create a conducive environment with availability of all possible resources needed(Weiner et al., 2008).

Majority of the respondents of this research believed that their institute have abilities that are needed to implement this change, with a mean value $\mathrm{M}=3.45$ and $\mathrm{SD}=0.764$. Some of the respondents believe that they have been part of well executed changes in the past, andwere found confident in their capacity to implement change with a mean value of $\mathrm{M}=3.37$ and $\mathrm{SD}=0.899$. Few respondents believed that the previous troubles in coping the change would replicate in the implementation of this process too (mean value 3.14 and $\mathrm{SD}=0.868$ ). Research studies suggest that higher the degree of change commitment and change efficacy, higher will be the chances of successful implementation of change process(Weiner et al., 2008).

The second subscale was about leaders of the change project. The top most perception of the respondents about it is, the leaders of change project should have the authority to carry out implementation with the values of $\mathrm{M}=3.68$ and $\mathrm{SD}=1.135$. The respondents also agree that leaders of the change project should accept full responsibility for the project and used to work well with the implementation team and share 
the responsibility for the project. Studies suggest that the respondents of change process are affected by both internal and external pressures, but an effective leadership can help them to overcome these pressures and stay motivated(Ajmal, Farooq, Sajid, \& Awan, 2012).

Regarding implementation team members the majority of respondents believed that they have clearly defined roles and responsibilities, with values of $\mathrm{M}=3.51$ and $\mathrm{SD}=0.938$.

The respondents also believe that in their institutes majority of the staff members are willing to innovate or experiment to improve their teaching and they also feel the responsibility for improving education with the top most having values $\mathrm{M}=3.57$ and $\mathrm{SD}=0.591$.

The departments are consulted about the change sufficiently is at the top of the list with the M=3.68 and $\mathrm{SD}=0.686$, followed by the belief that the staff members are sufficiently informed about the reason for the change. It was evident from the results staff members are sufficiently informed about the progress of the change. The vision of this change project is widely communicated and understood throughout the medical school. Majority of the respondents were agreed and strongly agreed that iinformation provided about the change is clear and good communication between project leaders and staff members about the school's policy is the authenticity towards the change. Studies suggest that, communication of the curriculum is an essential component of change process. Lack of communication can result in rumours, which will increase negativity and resistance against the change process(Elving, 2005).

Another subscale within the domain of capability is 'project resources'. The availability of resources is an important component of organizational readiness for successful change implementation. This study reveals that all respondents strongly agreed that staff development is essential for change process and this is the reason their institutes focussing on faculty and student training workshops. Sufficient staff and facilities (such as teaching rooms, books, and computers) must be provided to encounter challenges related to change in curriculum. In addition, the student awareness/needs and evaluation protocol, financial resources and incentives for staff to support the change project (financial, material or promotional) must be provided. Studies show that financial issues and unavailability of resources are the most common causes of impeding the change process; therefore one should elicit curricular changes that should not exceed the budget of an organization(Ferris \& Joyce, 2015).

This study also provided information about planning; the data revealed that it was done before initiating the changes. The data showed high mean and low standard deviation value for the indicator related to appropriate faculty and student training. Similar studies conducted suggests that proper faculty training before implementing a change is mandatory in order to overcome issues related to change of curriculum(Muller, Jain, Loeser, \& Irby, 2008b) and will help to produce more knowledgeable faculty members(Steinert, Cruess, Cruess, \& Snell, 2005).In addition, the study clearly described the tasks and long run timelines and identifies specific roles and responsibilities for the staff. Most of the respondents have view point that the institute should acknowledge staff input and opinion.

The respondents told that external innovativeness inhibition is the only hindrance in welcoming the change in curriculum. The most prevailing problem to welcome change in curriculum is the increase of workload of the faculty. Studies suggest that curriculum change can increase the workload of faculty leading to burnout and stress(Arvandi et al., 2016). The next highest external inhibition is the feeling among departments to lose power in controlling the teaching of their disciplines. The third indicator of inhibition of change is to feel restricted by strong hierarchy to express their views. Some respondents feel that there is ineffective cooperation between departments concerning educational issues and they afraid to lose income when this change is implemented. Most of the respondents told that they need change because it is imposed on them by their management. The respondents were agreed and strongly agreed that they feel pressure to go along the change.

\section{Conclusion}


It was concluded that all major scales as (motivation, capability, and extrinsic motivation) are reliable to measure organizational readiness for curriculum change. Although all other subscales ( pressure for change, need for change, appropriateness, efficacy, the leaders of change project, team members, staff innovativeness, communication, project resources, implementation plan for change, external innovativeness inhibition, and extrinsic motivation to change), are efficient and reliable. Whereas, It was noted that only three variables were found non-significant (pressure for change, need for change and appropriateness), and all other variables were effective. Results were also notable that majority of the respondents opined that their medical schools are in preparatory phase, some institutes are in two years implementation phase, and some are in first two years of implementation phase.

\section{Recommendations for Further Research}

1. MORC is a reliable instrument for assessing institutional preparedness for curriculum change.

2. Although MORC focuses on faculty but the role of students cannot be denied. Students obviously have an important contribution to make to curriculum change. In future research it would be interesting to combine MORC results with students' opinions.

3. The study included participants from schools in the preparation or implementation phase of curriculum change, and in future research it would be interesting to administer MORC in medical schools in the institutionalization phase to determine, in retrospect, whether determinants of successful change vary between the phases of curriculum change.

\section{References}

Ajmal, S., Farooq, M., Sajid, N., \& Awan, S. (2012). Role of leadership in change management process. Abasyn University Journal of Social Sciences, 5(2), 111-124.

Arvandi, Z., Emami, A., Zarghi, N., \& Education, M. (2015). Linking medical faculty stress / burnout to willingness to implement medical school curriculum change : 1-7. https://doi.org/10.1111/jep.12439

Arvandi, Z., Emami, A., Zarghi, N., \& Education, M. (2015). Linking medical faculty stress / burnout to willingness to implement medical school curriculum change : 1-7. https://doi.org/10.1111/jep.12439

Arvandi, Z., Emami, A., Zarghi, N., Alavinia, S. M., Shirazi, M., \& Parikh, S. V. (2016). Linking medical faculty stress/burnout to willingness to implement medical school curriculum change: A preliminary investigation. Journal of Evaluation in Clinical Practice, 22(1), 86-92. https://doi.org/10.1111/jep.12439

Bakari, H., Hunjra, A. I., \& Niazi, G. S. K. (2017). How Does Authentic Leadership Influence Planned Organizational Change? The Role of Employees' Perceptions: Integration of Theory of Planned Behavior and Lewin's Three Step Model. Journal of Change Management, 17(2), 155-187. https://doi.org/10.1080/14697017.2017.1299370

Bank, L., Jippes, M., Leppink, J., Jja Scherpbier, A., Den Rooyen, C., Van Luijk, S. J., \& Scheele, F. (2017). Advances in Medical Education and Practice Dovepress Are they ready? Organizational readiness for change among clinical teaching teams. Advances in Medical Education and Practice, 8, 807-815. https://doi.org/10.2147/AMEP.S146021

Bland, C. J., Starnaman, S., Wersal, L., Moorhead-rosenberg, L., Zonia, S., \& Henry, R. (2000). Curricular Change in Medical Schools: How to Succeed. 575-594.

Bland, C. J., Starnaman, S., Wersal, L., Moorhead-Rosenberg, L., Zonia, S., \& Henry, R. (2000). Curricular change in medical schools: How to succeed. Academic Medicine, Vol. 75, pp. 575-594. https://doi.org/10.1097/00001888-200006000-00006

Elving, W. J. L. (2005). The role of communication in organisational change. Corporate Communications, 10(2), 129-138. https://doi.org/10.1108/13563280510596943 
Ferris, H. A., \& Joyce, P. (2015). Factors Influencing Curricular Reform; an Irish Perspective. International Journal of Higher Education, 4(2), 38-43. https://doi.org/10.5430/ijhe.v4n2p38

Frenkel, M., Frye, A., Heliker, D., Finkle, T., Yzaguirre, D., \& Bulik, R. (2007). curriculum change Lessons learned from complementary and integrative medicine curriculum change in a medical school. 205-213. https://doi.org/10.1111/j.1365-2929.2006.02654.x

Fullan Dingle Associates, Inc., Washington, D. C., \& Michael Dingle Associates, Inc., Washington, D. C. (1983). Change Processes and Strategies at the Local Level. (6).

Garrison, D. R., \& Vaughan, N. D. (2013). Internet and Higher Education Institutional change and leadership associated with blended learning innovation: Two case studies. The Internet and Higher Education, 18, 24-28. https://doi.org/10.1016/j.iheduc.2012.09.001

Garrison, D. R., \& Vaughan, N. D. (2013). Internet and Higher Education Institutional change and leadership associated with blended learning innovation: Two case studies. The Internet and Higher Education, 18, 24-28. https://doi.org/10.1016/j.iheduc.2012.09.001

Hubball, H., \& Burt, H. (2004). An Integrated Approach to Developing and Implementing Learningcentred Curricula. 9(1), 51-65. https://doi.org/10.1080/1360144042000296053

Mcleod, P., \& Steinert, Y. (2014). Twelve tips for curriculum renewal. Medical Teacher, 1-7. https://doi.org/10.3109/0142159X.2014.932898

Meyer, J. P., \& Herscovitch, L. (2001). Commitment in the workplace: Toward a general model. Human Resource Management Review, 11(3), 299-326. https://doi.org/10.1016/S1053-4822(00)00053-X

Sandelowski, M. (2000). Combining Qualitative and Quantitative Sampling, Data Collection, and Analysis Techniques in Mixed- Method Studies. Research in Nursing \& Health, 23(3), 246-255. https://doi.org/10.1002/1098-240x(200006)23:3<246::aid-nur9>3.3.co;2-8

Steinert, Y., Cruess, S., Cruess, R., \& Snell, L. (2005). Faculty development for teaching and evaluating professionalism: From programme design to curriculum change. Medical Education, 39(2), 127-136. https://doi.org/10.1111/j.1365-2929.2004.02069.x

Tavakol, M., Murphy, R., \& Torabi, S. (2006). Medical Education in Iran: An Exploration of Some Curriculum Issues. Medical Education Online, 11(1), 4585. https://doi.org/10.3402/meo.v11i.4585

Wanberg, C. R., \& Banas, J. T. (2000). Predictors and outcomes of openness to changes in a reorganizing workplace. Journal of Applied Psychology, 85(1), 132-142. https://doi.org/10.1037/00219010.85.1.132

Weiner, B. J., Amick, H., \& Lee, S. Y. D. (2008). Review: Conceptualization and measurement of organizational readiness for change. A review of the literature in health services research and other fields. In Medical Care Research and Review (Vol. 65). https://doi.org/10.1177/1077558708317802

Woollins, J. D. (1992). The Preparation and Structure of Metalla-Sulphur/Selenium Nitrogen Complexes and Cages. Studies in Inorganic Chemistry, 14(C), 349-372. https://doi.org/10.1016/B978-0-44488933-1.50023-4 